\title{
Multipotent Islet-1 Cardiovascular Progenitors in Development and Disease
}

\author{
A. NAKano, ${ }^{*}$ H. NAKANO, ${ }^{*}$ AND K.R. ChIEN \\ Cardiovascular Research Center, Massachusetts General Hospital, Harvard Stem Cell Institute, \\ Department of Stem Cell and Regenerative Biology, Harvard Medical School, Boston, Massachusetts 02114-2790
}

\begin{abstract}
During the past several years, advances at the intersection of cardiovascular development and heart stem cell biology have begun to reshape our view of the fundamental logic that drives the formation of discrete tissue components in the mammalian heart. Although many of the critical genes that control cardiac myogenesis have been identified, our understanding of how a highly diverse and specialized subset of heart cell lineages arises from mesodermal precursors and is subsequently assembled into distinct muscle chambers, coronary arterial tree and large vessels, valvular tissue, and conduction system/pacemaker cells remains at a relatively primitive stage. Recent studies have uncovered a diverse group of closely related heart progenitors that are central in controlling and coordinating these complex steps of cardiogenesis. Understanding the pathways that control their formation, renewal, and subsequent conversion to specific differentiated progeny forms the underpinning for unraveling the pathways for congenital heart disease and has direct relevance to cardiovascular regenerative medicine. This current brief review highlights the discovery and delineation of the role of Islet- 1 cardiovascular progenitors in the generation of diverse heart cell lineages and how the implications of these findings are revising our classification and thinking about congenital heart disease in general.
\end{abstract}

The mammalian heart is a complex multichambered organ consisting of two ventricles, two atria, outflow tract and inflow tract, conduction system, valves, endocardium, and epicardium. The proper function of the whole heart requires a highly coordinated process of differentiation and integration of all of the cellular components (Olson 2006; Srivastava 2006). One of the central questions in cardiovascular biology relates to how these various components are assembled from early mesodermal precursors located in the heart field in the early mammalian embryo.

The cardiac precursor cells are specified in the anterior part of the primitive streak shortly after gastrulation. These precursor cells migrate toward the anterior lateral plate mesoderm and form a pair of cardiac crescents, the first visible and morphologically distinguishable structure of the cardiac primordia. Endocardial tubes are already formed in each of cardiac crescents at this stage. As the neuroectoderm develops rapidly at this stage, the heartforming region is pushed ventrally and fuses to form a single linear heart tube. It has been long thought that the identity of each heart chamber is already specified at an early stage within each segment of the linear heart tubeoutflow tract, right ventricle, left ventricle, atria, and sinus venosus, from the cranial to caudal direction.

The discovery of the second progenitor source has begun to challenge this classical segmental prespecification view of cardiogenesis and is reshaping our view of congenital heart abnormalities (Buckingham et al. 2005). This second source of cardiac progenitors is formed in the dorsomedial part of the anterior lateral plate mesoderm adjacent to the

*Present address: Department of Molecular, Cell \& Developmental Biology, Eli and Edythe Broad Center of Regenerative Medicine and Stem Cell Research, University of California, Los Angeles. cardiac crescent (Fig. 1). Recently, this extra-crescent heart field (second heart field; SHF) was revisited and characterized by several different techniques: dye labeling, detection of specific molecular markers, and retrospective singlecell-fate tracing experiments (Kelly et al. 2001; Mjaatvedt et al. 2001; Waldo et al. 2001; Cai et al. 2003; Dodou et al. 2004; Meilhac et al. 2004). Different methods and different markers have determined slightly different populations of the cardiac progenitors, which has led to the initial confusion of the definition of SHF and anterior heart field (AHF). The SHF is well delineated by the expression of Isl1, a member of the LIM homeodomain transcription factor family (Cai et al. 2003), whereas several other molecular markers, such as FGF8/10, Wnt11, and a specific Mef2c enhancer, label the anterior subset of SHF. In this chapter, "SHF" is used in a broader sense, including both the anterior heart field subset and the posterior subset that mainly contributes to the atria and inflow tract.

The dorsal mesocardium, the mesentery that suspends the linear heart tube, is initially continuous to the splanchnic mesoderm at any level at the linear heart tube stage. Cardiac progenitor cells in the splanchnic mesoderm continue to migrate through the dorsal mesocardium. As the dorsal mesocardium breaks down, the heart tube becomes connected to the body wall only at the arterial pole and the venous pole. From this point, the SHF progenitors migrate to the heart tube at either pole.

The rightward looping of the heart tube is then triggered by the addition of second heart field progenitors onto the scaffold of the primary heart tube and subsequent segmental ballooning of outer curvature of each chamber. The rapid growth of each segment places the forming atria and inflow portion above the ventricular chambers. The rightward looping is the first appearance of left-right asymmetry in the heart. Obviously, the rapid growth of the polar compart- 

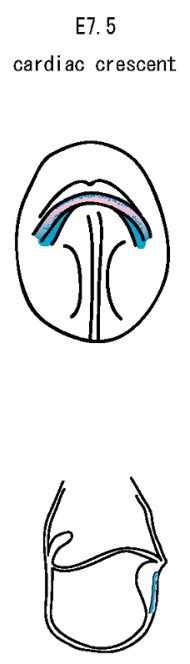

Primary Heart Field Secondary Heart Field
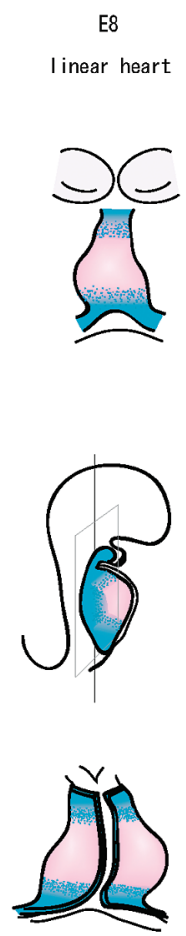

E8. 5-9

looping heart

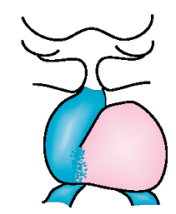

frontal view

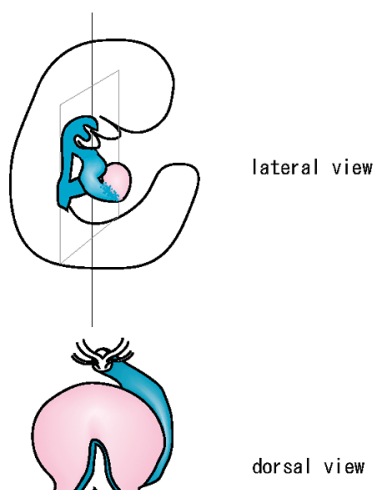

Figure 1. Morphogenesis of the mouse embryonic heart. The primordia of the heart are first morphologically recognizable as the cardiac crescent. Whereas the cells in the first heart field (FHF, pink) mainly contribute to the formation of the cardiac crescent, the cells in the second heart field (SHF, blue) appear in extra-crescent tissue. At around E8, bilateral crescents fuse in the midline to form a single linear heart tube. The primary heart tube is mainly composed of FHF cells, but SHF cells start to migrate toward the primary heart tube through the dorsal mesocardium, which is still continuous to the heart tube at any level at this stage. As the dorsal mesocardium dissolves, the heart tube become suspended by two poles, creating two subpopulations of SHF cells: anterior/arterial pole/outflow tract population and posterior/venous pole/inflow tract population. The anterior subpopulation gives rise to the myocardium of the outflow tract and right ventricle and acquires the ventricular phenotype. The posterior population contributes mainly to atrial myocytes and acquires the atrial phenotype. Concomitant with this, the heart tube starts to undergo rightward looping (d loop).

ments by itself is not the primary initiator of the asymmetry but an enhancer of preexisting laterality information.

After the cardiac chambers are positioned as seen in the postnatal heart, the heart undergoes a series of septation events. The formation of the conotruncal part of the heart requires the contribution of two distinct cell types: cardiac neural crest and second heart field progenitors. These two populations have distinct developmental origins, but they migrate through the pharyngeal mesoderm in a closely related pathway (Kelly and Buckingham 2002). Cardiac neural crest cells arise from the dorsal neural tube at the level of rhombomeres 6-8 and migrate into the arterial pole of the looping heart tube (Stoller and Epstein 2005; Hutson and Kirby 2007; Snider et al. 2007). This specific population of the neural crest contributes to the septum of the outflow tract and the smooth muscle wall of the ascending aorta, aortic arch, and orifice of the left and right coronary arteries. Simultaneously to this septation event, the outflow myocardium of the second heart field origin undergoes shortening. Ablation of either cell population results in the hypoplasia and rotation defects of the cardiac outflow tract (Yelbuz et al. 2002; Baldini 2005). Therefore, the interaction of these two populations has an important role in the morphogenesis of the cardiac outflow tract (Waldo et al. 2005a).

Endocardial cushions also contribute to the formation of septa as well as the valves. After the completion of the looping, endocardial cells at both ends of the heart tubeoutflow tract and atrioventricular (AV) canal-transform into mesenchymal cell types and migrate into the cardiac jelly between endocardial and myocardial layers to form endocardial cushions. Cushions in the outflow portion are the primordia of the outflow septum and semilunar valves, and the cushion in the AV canal gives rise to atrial and ventricular septa and the AV valves.

\section{CELL-FATE MAP}

The earliest process of mammalian cardiogenesis has largely been a black box, partly because of the technical inaccessibility to the embryo at this stage. Instead, this step has been intensively studied in lower vertebrates (chick, amphibians, zebra fish) and nonvertebrate (fly) models. These nonmammalian models suggested that at least part of the endothelial/endocardial lineage shares a common origin with cardiac precursors. Recent advances in mouse genetics and embryonic stem (ES) cell technology have enabled us to study this process at the cellular level in mammals (Fig. 2). Mesodermal precursor cells expressing Flk1/Brachyury ( $\mathrm{T}$ ) and early cardiac progenitors labeled by Is11/Nkx2.5/ Flk1 are shown to be capable of differentiating into cardiac, smooth muscle, and endothelial lineages from single cells (Garry and Olson 2006; Kattman et 


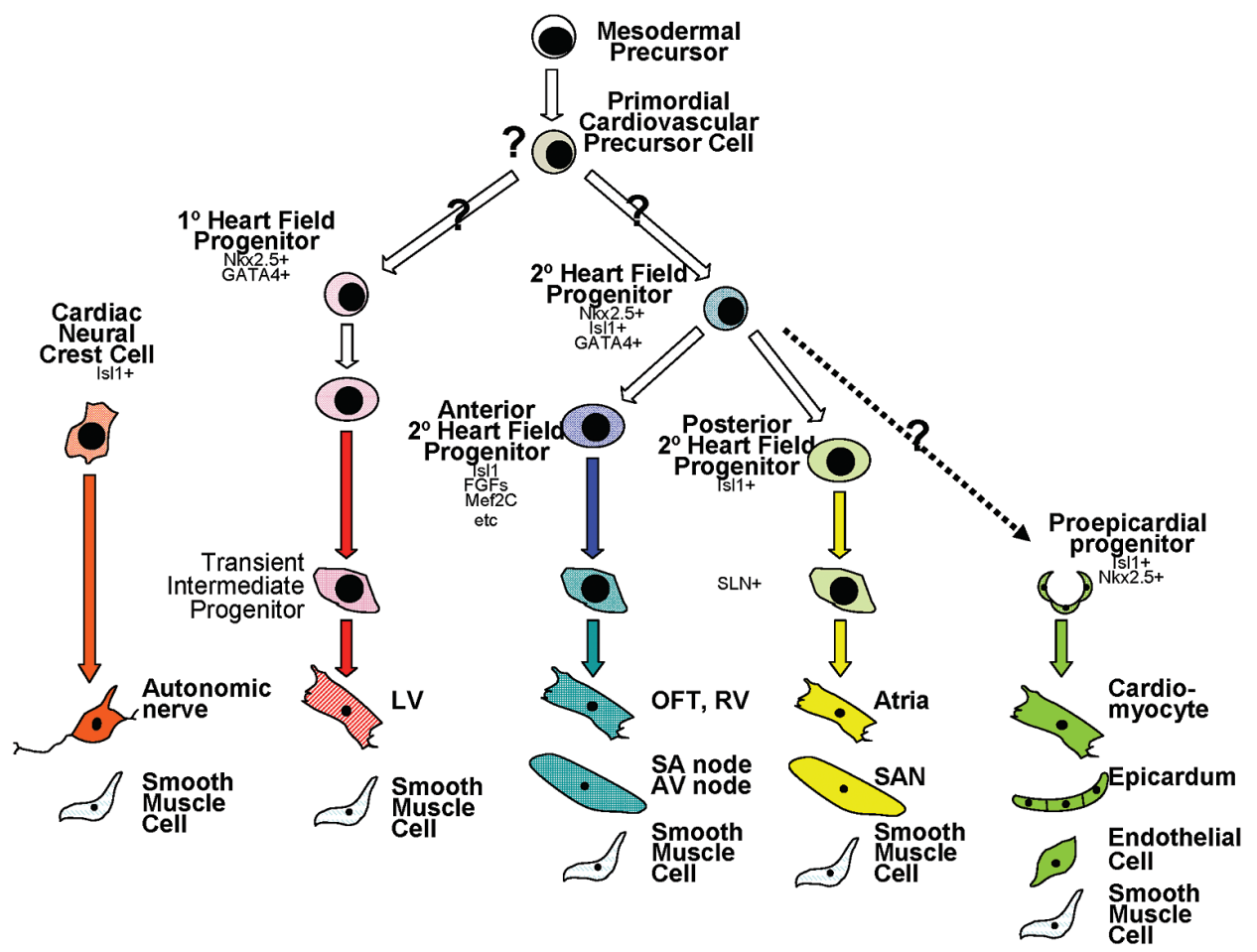

Figure 2. A model for cell-fate map of cardiac progenitors. Putative common precursor cells are specified from mesodermal precursors shortly after gastrulation. This common precursors give rise to first (Is11-) and second $\left(\mathrm{Is}^{-} 1^{+}\right)$heart field progenitors (FHF and SHF). The SHF population can be further subdivided into anterior and posterior secondary heart field subpopulations. The FHF population gives rise to the left ventricle (red); the anterior SHF population gives rise to the outflow tract, right ventricle, and AV nodal cells; and the posterior SHF population contributes mainly to atrial myocytes and SA nodal cells. Proepicardial progenitor cells may share a common origin with SHF progenitors (they also give rise to cardiomyocytes, express early cardiac markers Isl1 and Nkx2.5, and arise in close vicinity to the posterior SHF). (LV) Left ventricle; (OFT) outflow tract; (RV) right ventricle; (SA) sinoatrial; (AV) atrioventricular; (SAN) sinoatrial node.

al. 2006, 2007; Moretti et al. 2006; Martin-Puig et al. 2008; Yang et al. 2008). Mesp1 acts as a master regulator during the commitment of mesodermal cells into cardiac lineages (Bondue et al. 2008; Lindsley et al. 2008; Wu 2008). Whereas endothelial lineages separate from cardiac and smooth muscle lineages at an early stage, cardiac and smooth muscle lineages are closely related until later stages of cardiogenesis (Wu et al. 2006). Smooth muscle cells appear to be recruited locally from a wide range of mesodermal tissues and differentiate in response to local inductive signals (Waldo and Kirby 1993; Topouzis and Majesky 1996; Waldo et al. 2005b; Majesky 2007).

Using in vivo retrospective clonal assays, Meilhac et al. (2004) showed that cardiac progenitors come from two major origins corresponding to the FHF and SHF. Both FHF and SHF progenitors contribute to most of the cardiac regions except for the left ventricle (mainly FHF) and outflow tract (mainly SHF), challenging the classical segmental view of cardiogenesis. Furthermore, they also speculate that these two lineages likely originate from putative common precursors. It remains to be answered whether there is a fundamental functional difference other than the marker expression between these two populations and whether these two are mutually exchangeable. Indeed, there are no morphological differences between the progenitors in FHF and SHF at a cellular level, nor are there clear morphological boundaries at the cardiac crescent stage. Even in the postnatal heart, there are no obvious morphological differences among cardiomyocytes in OFT/RV and LV at the cellular level. Recent analysis suggests the possibility that Isl1 is transiently expressed in the FHF (Prall et al. 2007), although lineage-tracing studies support the concept of a distinct SHF subset of progenitors. Thus, the argument still remains as to whether it is relevant to define so-called SHF as another "organ field" of the heart (Abu-Issa et al. 2004; Moorman et al. 2007). Current studies designed to purify and tag specific subsets of FHF and SHF heart progenitors from ES cells and earlystage embryos should help to resolve this issue.

The breakdown of dorsal mesocardium further subdivides SHF into two major cardiac progenitor populations: anterior/arterial pole/outflow populations and posterior/ venous pole/inflow populations (Fig. 3). The anterior population is labeled by several molecular markers, including fibroblast growth factors (FGFs), bone morphogenetic protein (BMPs), Wnt11, and a specific enhancer of Mef2c (Kelly et al. 2001; Cai et al. 2003; Dodou et al. 2004; Lin et al. 2007), and eventually acquires the ventricular phenotype contributing to the outflow tract and right ventricle. The posterior population eventually gives rise to atrial myocardium (Galli et al. 2008). The posterior population may also contribute to multiple lineages, such as the 
E8

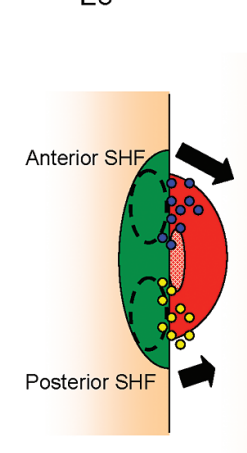

E8.5

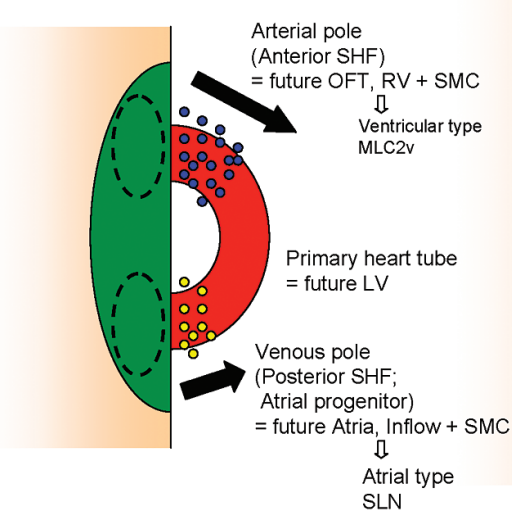

E9.0

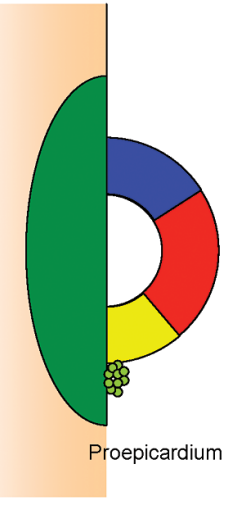

Figure 3. Migration of anterior and posterior population of SHF progenitors. Shortly after the formation of the linear heart tube, the anterior SHF progenitors migrate to the arterial pole of the primitive heart tube. This population is marked by FGF8/10 and the specific enhancer of Mef2c. The anterior population eventually acquires the ventricular phenotype and gives rise to the cardiomyocytes in the outflow tract and right ventricle, as well as smooth muscle cells in the base of the ascending aorta. The posterior subpopulation of the SHF migrates toward the venous pole and contributes to atrial myocytes and myocardial sleeves, as well as to smooth muscle cells in the cardiac inflow. Note that the proepicardium arises from the boundary between the embryonic liver and sinus venosus and thus spatially and temporarily continuous to the posterior SHF.

Tbx $18^{+}$population (Christoffels et al. 2006) and mediastinal myocardial population (Anderson et al. 2006; Snarr et al. 2007a,b). Identification of additional specific molecular markers will further help to establish the cellular hierarchy of cardiac lineages (Laugwitz et al. 2008).

Recent findings suggest that the proepicardium may be another source of cardiomyocytes (Cai et al. 2008; Zhou et al. 2008). The proepicardium is a pair of grape-like clusters of epithelial cells that arise between the sinus venosus and liver primordium. Using retroviral tagging methods, Mikawa and Gourdie (1996) proved the speculation by Goor and Lillehei (1975) that the proepicardium is the source of the coronary vasculature. A combinatorial approach using mouse genetic models and the ES system showed that proepicardial cells also contribute to some of the cardiomyocytes (Cai et al. 2008; Zhou et al. 2008). These proepicardial progenitor cells are positive for both Is 11 and Nkx2.5. Given that the proepicardium is spatially and temporarily continuous to the posterior population of SHF, the proepicardial progenitors may share a common origin with cardiac progenitors in the SHF.

Apart from the argument regarding the expression of Isl1 in the FHF, Isl1 is expressed in most of the other cardiac lineages, as well as the proepicardial lineages. Hence, Isl1 labels a pool of various cardiac progenitor subpopulations. Although Is11 is down-regulated as the cardiomyocytes mature, it stays on until a later stage in some subsets and turns off early in other subsets. Notably, these diverse progenitor populations arise from the spatiotemporal continuity of the Isl1-positive field of the primordial heart. The common function of the Isl1 transcription factor in these diverse populations is of interest. Obviously, Isl1 is expressed in proliferative cardiac progenitors. Our recent data show that Isl1 expression strongly correlates with cell cycle activity (A. Nakano et al., unpubl.). Therefore, Is11 may well be regarded as a marker for proliferative progenitors during their transition to cardiomyocytes as well as for the cells early in the SHF lineage.

\section{CONGENITAL HEART DISEASE AND ISL1 PROGENITOR}

Many monogenic heart diseases result in closely related phenotypes, suggesting that abnormalities of cardiac progenitors resulting from these genetic deficiencies may be fundamental to the pathogenesis of congenital heart disease. Identification of the cellular level of the defects in the cardiac progenitor lineages in these diseases should link molecular function of genes to the pathogenesis of congenital heart defects. Figure 4 displays several of the human congenital heart defects associated with gene mutations. Although studies in model systems have shown that Isl1 is expressed in a variety of cardiac lineages and has a pivotal role in the transcription network during cardiogenesis (Black 2007), it is currently of major interest to determine if Isl1 genetic variation might relate to human congenital heart abnormalities.

\section{CARDIAC OUTFLOW TRACT AND WNT/ß-CATENIN SIGNALING}

Many of the key major signaling molecules such as BMP, FGF, Shh, Wnt, and Notch are also implicated in multiple processes of cardiogenesis. Among these signals, the $\mathrm{Wnt} / \beta$-catenin pathway is unique in that it has a highly context-dependent role during cardiogenesis. Early in avian cardiogenesis, canonical Wnt signals from the neuroectoderm are known to inhibit the specification of cardiac progenitors, resulting in a crescent-shaped heart-forming region (Marvin et al. 2001; Schneider and Mercola 2001; Tzahor and Lassar 2001). Mouse ESbased data mostly suggest a positive effect of $\mathrm{Wnt} / \beta$ catenin signaling on the appearance of beating cardiomyocytes (49-52). Genetic loss- and gain-of-function experiments using various Cre mice mostly resulted in the conclusion that $\mathrm{Wnt} / \beta$-catenin is involved in expansion of the cardiac progenitor population (Naito et al. 2006; Cohen et al. 2007; Klaus et al. 2007; Kwon et al. 


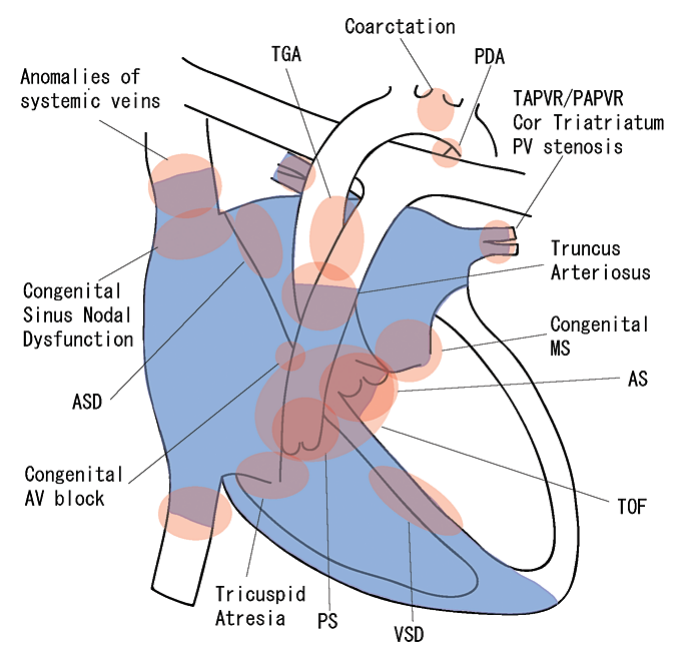

Figure 4. Distribution of Is11-positive progenitor-derived cells and congenital heart disease. (AS) Aortic stenosis; (ASD) atrial septal defect; (AV) atrioventricular; (MS) mitral stenosis; (PDA) patent ductus arteriosus; (PS) pulmonary stenosis; (PV) pulmonary vein; (TAPVR/PAPVR) total/partial anomalous pulmonary venous return; (TGA) transposition of great arteries; (TOF) tetralogy of Fallot.

\begin{tabular}{|c|c|c|}
\hline \multicolumn{2}{|c|}{ Isl1-derived cells } & Congenital anomalies \\
\hline \multicolumn{3}{|l|}{ Outflow tract defects } \\
\hline \multicolumn{3}{|l|}{ Aortic stenosis } \\
\hline Fibromuscular subvalvar & $\circ$ & NKX2.5 (A) \\
\hline Bicuspid aortic valve & $\circ$ & Notch2 (Alagille) (B) \\
\hline Supravalvar (SVAS) & 。 & Elastin (Williams-Beuren) (C) \\
\hline Pulmonary stenosis & $\circ$ & $\begin{array}{l}\text { NF1 (D), Jag1 (Alagille) (E), Notch2 (Alagille) (B), PTPN11/Shp2 (Noonan) (F), } \\
\text { MEK1/2 (G), B-Raf//H/K-Ras (H), GATA4 (I) }\end{array}$ \\
\hline \multicolumn{3}{|r|}{ (1) } \\
\hline RV/OFT obstruction, overriding aorta & $\circ$ & Jag1 (Alagille) (E), Notch2 (Alagille) (B), NKX2.5 (A) \\
\hline Double-outlet right ventricles & 。 & CFC1 (J), NKX2.5 (A), GATA4 (I) \\
\hline Truncus arteriosus & 。 & TBX1 (DiGeorge) (K), VEGF promotor (DiGeorge) (L) \\
\hline Transposition of great arteries & $\circ$ & ZIC3 (M), CFC1 (J), THRAP2 (N) \\
\hline \multicolumn{3}{|l|}{ Inflow tract defects } \\
\hline Cor triatriatum & ? & \\
\hline TAPVR and PAPVR & ? & \\
\hline Anomalies of systemic veins & $\circ$ & NKX2.5 (A) \\
\hline \multicolumn{3}{|l|}{ Septation defects } \\
\hline VŚD & $\circ$ & $\begin{array}{l}\text { TBX1 (DiGeorge) (O), TBX5 (P), CHD7 (CHARGE) (Q), Sema3E (CHARGE) (R), } \\
\text { NKX2.5 (A), GATA4 (I) }\end{array}$ \\
\hline ASD & $\circ$ & $\begin{array}{l}\text { TBX5 (P), CHD7 (CHARGE) (Q), Sema3E (CHARGE) (R), NKX2.5 (A), GATA4 (I), } \\
\text { TBX20 (S), MYH6 (T) }\end{array}$ \\
\hline AVSD (endocardial cushion defect) & $\circ$ & GJA1 (U), CRELD1 (V), FOG2 (W), GATA4 (I) \\
\hline \multicolumn{3}{|l|}{ Valvular defects } \\
\hline Tricuspid atresia & ? & NKX2.5 (Epstein) (A) \\
\hline \multicolumn{3}{|l|}{ Defects in aortic remodeling } \\
\hline Patent ductus arteriosus (usually secondary) & 。 & TFAP2 $\beta(X)$ \\
\hline Coarctation of the aorta & 。 & TBX1 (DiGeorge) (O) \\
\hline Aortopulmonary septal defect (AP window) & 。 & \\
\hline \multicolumn{3}{|l|}{ Coronary defects } \\
\hline Anomalous origin of coronary arteries & $\circ$ & \\
\hline $\begin{array}{l}\text { Congenital distal coronary defects } \\
\text { (fistula, aneurysm, stenosis, hypoplasia) }\end{array}$ & $\circ$ & \\
\hline \multicolumn{3}{|l|}{ Congenital cardiac conduction system defects } \\
\hline Congenital sinus nodal dysfunction & $\circ$ & SCN5A $(\mathrm{Y})$ \\
\hline WPW syndrome & ? & PRKAG2 (Z) \\
\hline Congenital AV block & $\circ$ & TBX5 (P), NKX2.5 (A) \\
\hline Long QT syndrome & $\mathrm{x}$ & KCNQ1, KCNH2, KCNE1, KCNE2, CACNA1c, CAV3, SCN5A, SCN4B, HCN4 \\
\hline RBBB & ? & TBX5 (P) \\
\hline \multicolumn{3}{|l|}{ Left ventricular defects } \\
\hline Hypoplastic left heart syndrome & $\mathrm{x}$ & GJA1 (U) \\
\hline Left ventricular noncompaction syndrome & $\mathrm{x}$ & DTNA (ZZ), NKX2.5 (Epstein) (A) \\
\hline
\end{tabular}

References: (A) Schott et al. 1998; Benson et al. 1999; Kasahara et al. 2000; Goldmuntz et al. 2001; Gutierrez-Roelens et al. 2002; Ikeda et al. 2002; Watanabe et al. 2002; McElhinney et al. 2003; Kasahara and Benson 2004; Pashmforoush et al. 2004; (B) McDaniell et al. 2006; (C) Ewart et al. 1993; (D) Li et al. 1992; Bahuau et al. 1996, 1998; Lin et al. 2000; (E) Li et al. 1997a; Oda et al. 1997; (F) Tartaglia et al. 2001; (G) Rodriguez-Viciana et al. 2006; (H) Aoki et al. 2005; Niihori et al. 2006; Schubbert et al. 2006; (I) Pehlivan et al. 1999; Garg et al. 2003; Hirayama-Yamada et al. 2005; (J) Bamford et al. 2000; Goldmuntz et al. 2002; (K) Jerome and Papaioannou 2001; Lindsay et al. 2001; Merscher et al. 2001; Yagi et al. 2003; (L) Stalmans et al. 2003; (M) Gebbia et al. 1997; (N) Muncke et al. 2003; (O) Jerome and Papaioannou 2001; Lindsay et al. 2001; Merscher et al. 2001; (P) Basson et al. 1997; Li et al. 1997b; (Q) Vissers et al. 2004; (R) Lalani et al. 2004; (S) Kirk et al. 2007; (T) Ching et al. 2005; (U) Dasgupta et al. 2001; (V) Robinson et al. 2003; Zatyka et al. 2005; Maslen et al. 2006; (W) Pizzuti et al. 2003; (X) Satoda et al. 2000; Zhao et al. 2001; (Y) Benson et al. 2003; (Z) Gollob et al. 2001a,b; (ZZ) Ichida et al. 2001. 
2007; Qyang et al. 2007; Ueno et al. 2007). These results reflect the difference in each experimental system. First, $\mathrm{Wnt} / \beta$-catenin has various roles at different stages during cardiogenesis (stage dependency) (Tzahor 2007). Second, it is likely that the $\mathrm{Wnt} / \beta$-catenin pathway has a different role in various subsets of the progenitors (sublineage dependency). Third, many of the key signaling molecules and transcription factors are known to have different roles at different dosages and different gradients (dosage and gradient dependency). Fourth, in some cases, it is difficult to segregate specification, migration, and proliferation of the Isl1 progenitors in some models. Thus, the Wnt $/ \beta$ catenin pathway has a highly context-dependent role. However, despite all of the limitations of each experimental system, it is clear that the $\mathrm{Wnt} / \beta$-catenin pathway is one of the most promising signaling molecules from the viewpoint of future therapeutic application.

\section{ANCHORING ATRIAL CHAMBERS AND GREAT VEINS IN THE CARDIAC INFLOW TRACT}

As discussed above, the SHF delineated by Isl1 can be subdivided into two major cardiac populations: the anterior subpopulation in the arterial pole and the posterior subpopulation in the venous pole of the heart tube (Fig. 3) (Galli et al. 2008). Isl1-positive cardiac progenitors that populate in the anterior SHF/arterial pole of the primitive heart tube give rise to both cardiomyocytes and smooth muscle cells in the cardiac outflow tract (Waldo et al. 2005b). Analogous to this observation, we have recently found that Isl1-positive cardiac progenitors in the posterior $\mathrm{SHF} /$ venous pole give rise to atrial cardiomyocytes as well as smooth muscle cells in the cardiac inflow region (A. Nakano et al., unpubl.). Single-cell analysis using a cardiac mesenchymal feeder system revealed that this lineage diversification is controlled by the bipotency of atrial progenitors that express Is11 and sarcolipin (SLN), a marker for committed atrial cells.

An important biological question is why these Isl1-positive cardiac progenitors show bipotency until a relatively late stage and how this bipotency serves to coordinate the morphogenesis of atrial chambers and the great veins. One possibility is that bipotency is required to connect the boundary between the atrial chambers and great veins and to maintain the cardiac syncytium. In fact, when the differentiation of atrial progenitors is inhibited, murine embryos overexpressing $\beta$-catenin in the atrial lineage $\left(\mathrm{SLN}^{\mathrm{cre} /+} ; \beta \mathrm{cat}^{\mathrm{ex} 3 /+}\right)$ showed significantly smaller atria and inflow tracts compared with control littermates (Fig. 5 ). Some of the mutants examined showed a massive hemorrhage, possibly leaking from the boundary between atrial chamber and inflow veins. These data suggest that bipotency of atrial progenitors is required for anchoring the atrial chamber to the great veins and forming functional syncytia that facilitate the dynamism of the central circulation system. From a developmental perspective, it implies that the cells in the boundary of two different tissues have to be phenotypically plastic in order to glue these tissues and maintain anatomical and functional continuity. It would be of interest to determine whether the anterior/arterial pole population of the cardiac progenitors displays similar bipotency during cardiogenesis.

\section{CONGENITAL HEART DISEASE \\ AFFECTING THE DEVELOPMENT OF CARDIAC INFLOW TRACT}

The defect in the connection of the atrial chamber and great veins possibly has an important role in the pathogenesis of several particular congenital heart malformations (Fig. 4). Anomalous pulmonary venous return denotes a spectrum of malformations in which at least one pulmonary vein connects to the right atrium directly or
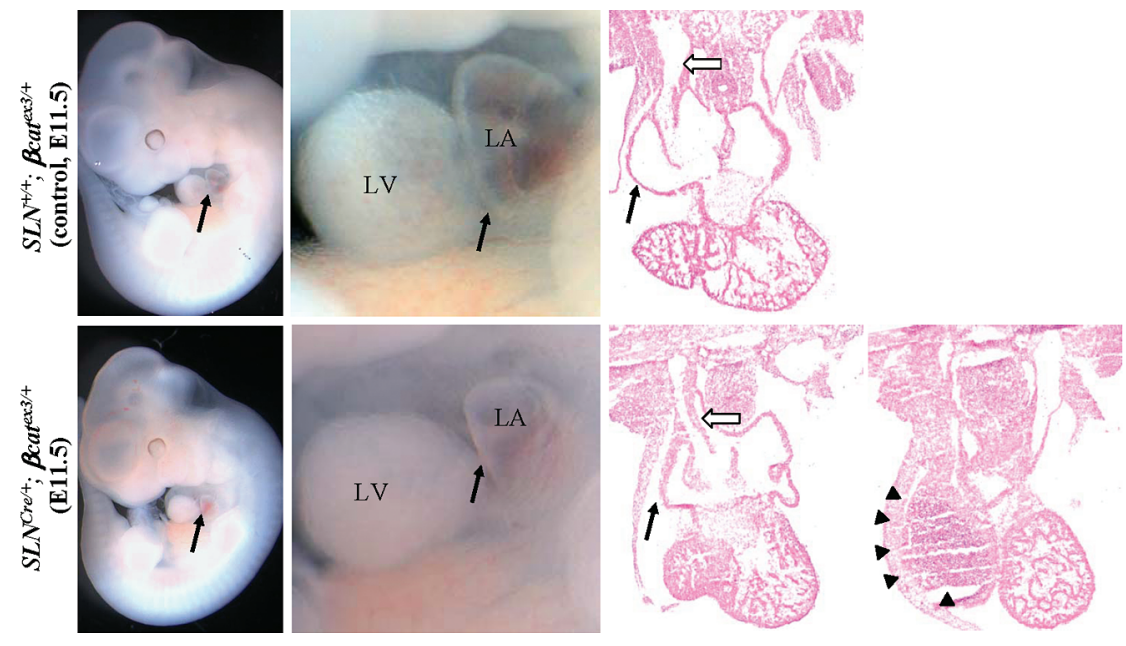

Figure 5. Inhibition of the differentiation of atrial progenitors results in the malformation of the boundary between the atrial chamber and great veins. The differentiation of atrial progenitors is inhibited by the overexpressing active form of $\beta$-catenin. The $\mathrm{SLN}^{\mathrm{cre} /+} ; \beta_{\mathrm{cat}}{ }^{\mathrm{ex} 3 /+}$ embryo showed significantly smaller atria (black arrows) and a narrower vena cava (white arrows). One of three mutants showed a massive hemorrhage, possibly due to the malconnection of the atrial chamber and great veins (arrowheads). These data suggest that the proper differentiation of atrial progenitors is required for anchoring the vascular smooth muscle wall to the myocardium of atria and for generating functional syncytium. (LV) Left ventricle; (LA) left atrium. 
through a systemic vein(s). This anomaly can be asymptomatic depending on the severity of the left-to-right shunt, and the incidence may be more common than we find from clinical cases. Cor triatriatum is another congenital heart disease in which the connection of pulmonary veins and left atrium is affected. The inadequate integration of the common pulmonary vein results in the formation of two chambers: the accessory chamber (enlarged common pulmonary vein) and the true left atrium. Mice have a common pulmonary vein that collects blood from four lobar pulmonary veins. Pulmonary vein stenosis is a congenital heart disease characterized by recurrent obstruction of pulmonary veins by proliferation of spindleshaped myofibroblasts of the junction between the pulmonary vein and the left atrial chamber (Sadr et al. 2000). Compared with the anomalies on the left side, the connection problem of the systemic veins to the right side of the heart is rare. Precise analysis of these human congenital diseases in the inflow tract will answer the questions of how the myocardial sleeves develop, how the boundary of atrial myocardium and vascular smooth muscle cells is formed during cardiogenesis, and the biological significance of the plasticity of atrial cells.

\section{RETRODIFFERENTIATION}

The Isl1/SLN atrial progenitors from the posterior/ venous part of the SHF maintain their migratory and proliferative potential even until midgestation. Consistent with this, Isl1 expression continues at E13.5 in mouse atria (Sun et al. 2007). The late development of atrial progenitors is likely linked to the fact that atrial progenitors remain bipotent until later stages of heart development. Atrial cells can acquire a smooth muscle and ventricular phenotype even after birth. Interestingly, this phenotypical plasticity is at least partially acquired by a retrodifferentiation process. Upon culture on cardiac feeder or upon in vivo injury, atrial cells reenter the cell cycle and reexpress the Isl1 that is not normally expressed in postnatal atrial myocytes. The cellular plasticity of the atrial cells in the inflow may be related to the pathogenesis of atrial fibrillation.

A number of stem/progenitor cell populations have been identified in the postnatal heart including c-kit-positive and Sca1-positive stem/progenitor cells and Is11positive progenitors that are embedded in cardiac mesenchyme and considered to be developmental remnants of the secondary heart field (Orlic et al. 2001; Beltrami et al. 2003; Oh et al. 2003; Laugwitz et al. 2005). Researchers speculate that regenerating zebra fish myocardium also arises from undifferentiated cardiac progenitors (Lepilina et al. 2006). The discovery of these preexisting stem/progenitor cells offers a great opportunity to regenerate the lost cardiomyocytes (Murry et al. 2005; Srivastava and Ivey 2006; Rubart and Field 2008). However, besides the activation of these residential undifferentiated stem/progenitor cells (dedifferentiation-independent regeneration), a trace of another mechanism of tissue regeneration may also take place in the heart: mature cells dedifferentiate, reenter the cell cycle, and redifferentiate another mature cell type (dedifferentia- tion-dependent mechanism). Further analysis using defined markers will lead to a better understanding of the pathogenesis of the above-mentioned congenital heart diseases, the normal developmental process of the atrial lineage, the cellular mechanism of their plasticity, and eventually the clinical usage of Is11-positive progenitor cells derived from atria.

\section{ACKNOWLEDGMENTS}

We thank all of our collaborators who contributed to the current work and to our ongoing research. Our studies are supported by LeDuq foundation, Harvard Stem Cell Institute, Massachusetts General Hospital, and the National Institutes of Health.

\section{REFERENCES}

Abu-Issa, R., Waldo, K., and Kirby, M.L. 2004. Heart fields: One, two or more? Dev. Biol. 272: 281-285.

Anderson, R.H., Brown, N.A., and Moorman, A.F. 2006. Development and structures of the venous pole of the heart. Dev. Dyn. 235: 2-9.

Aoki, Y., Niihori, T., Kawame, H., Kurosawa, K., Ohashi, H., Tanaka, Y., Filocamo, M., Kato, K., Suzuki, Y., Kure, S., et al. 2005. Germline mutations in HRAS proto-oncogene cause Costello syndrome. Nat. Genet. 37: 1038-1040.

Bahuau, M., Flintoff, W., Assouline, B., Lyonnet, S., Le Merrer, M., Prieur, M., Guilloud-Bataille, M., Feingold, N., Munnich, A., Vidaud, M., et al. 1996. Exclusion of allelism of Noonan syndrome and neurofibromatosis-type 1 in a large family with Noonan syndrome-neurofibromatosis association. Am. J. Med. Genet. 66: 347-355.

Bahuau, M., Houdayer, C., Assouline, B., Blanchet-Bardon, C., Le Merrer, M., Lyonnet, S., Giraud, S., Recan, D., Lakhdar, H., Vidaud, M., et al. 1998. Novel recurrent nonsense mutation causing neurofibromatosis type 1 (NF1) in a family segregating both NF1 and Noonan syndrome. Am. J. Med. Genet. 75: 265-272.

Baldini, A. 2005. Dissecting contiguous gene defects: TBX1. Curr. Opin. Genet. Dev. 15: 279-284.

Bamford, R.N., Roessler, E., Burdine, R.D., Saplakoglu, U., dela Cruz, J., Splitt, M., Goodship, J.A., Towbin, J., Bowers, P., Ferrero, G.B., et al. 2000. Loss-of-function mutations in the EGF-CFC gene $\mathrm{CFCl}$ are associated with human left-right laterality defects. Nat. Genet. 26: 365-369.

Basson, C.T., Bachinsky, D.R., Lin, R.C., Levi, T., Elkins, J.A., Soults, J., Grayzel, D., Kroumpouzou, E., Traill, T.A., Leblanc-Straceski, J., et al. 1997. Mutations in human TBX5 (corrected) cause limb and cardiac malformation in HoltOram syndrome. Nat. Genet. 15: 30-35.

Beltrami, A.P., Barlucchi, L., Torella, D., Baker, M., Limana, F., Chimenti, S., Kasahara, H., Rota, M., Musso, E., Urbanek, K., et al. 2003. Adult cardiac stem cells are multipotent and support myocardial regeneration. Cell 114: 763-776.

Benson, D.W., Wang, D.W., Dyment, M., Knilans, T.K., Fish, F.A., Strieper, M.J., Rhodes, T.H., and George, Jr., A.L. 2003. Congenital sick sinus syndrome caused by recessive mutations in the cardiac sodium channel gene (SCN5A). J. Clin. Invest. 112: 1019-1028.

Benson, D.W., Silberbach, G.M., Kavanaugh-McHugh, A., Cottrill, C., Zhang, Y., Riggs, S., Smalls, O., Johnson, M.C., Watson, M.S., Seidman, J.G., et al. 1999. Mutations in the cardiac transcription factor $N K X 2.5$ affect diverse cardiac developmental pathways. J. Clin. Invest. 104: 1567-1573.

Black, B.L. 2007. Transcriptional pathways in second heart field development. Semin. Cell Dev. Biol. 18: 67-76.

Bondue, A., Lapouge, G., Paulissen, C., Semeraro, C., Iacovino, M., Kyba, M., and Blanpain, C. 2008. Mesp1 acts as a master regulator of multipotent cardiovascular progenitor specification. Cell Stem Cell 3: 69-84. 
Buckingham, M., Meilhac, S., and Zaffran, S. 2005. Building the mammalian heart from two sources of myocardial cells. Nat. Rev. Genet. 6: 826-835.

Cai, C.L., Liang, X., Shi, Y., Chu, P.H., Pfaff, S.L., Chen, J., and Evans, S. 2003. Isl1 identifies a cardiac progenitor population that proliferates prior to differentiation and contributes a majority of cells to the heart. Dev. Cell 5: 877-889.

Cai, C.L., Martin, J.C., Sun, Y., Cui, L., Wang, L., Ouyang, K., Yang, L., Bu, L., Liang, X., Zhang, X., et al. 2008. A myocardial lineage derives from Tbx18 epicardial cells. Nature 454: 104-108.

Ching, Y.H., Ghosh, T.K., Cross, S.J., Packham, E.A., Honeyman, L., Loughna, S., Robinson, T.E., Dearlove, A.M., Ribas, G., Bonser, A.J., et al. 2005. Mutation in myosin heavy chain 6 causes atrial septal defect. Nat. Genet. 37: 423-428.

Christoffels, V.M., Mommersteeg, M.T., Trowe, M.O., Prall, O.W., de Gier-de Vries, C., Soufan, A.T., Bussen, M., Schuster-Gossler, K., Harvey, R.P., Moorman, A.F., et al. 2006. Formation of the venous pole of the heart from an Nkx2-5-negative precursor population requires Tbx18. Circ. Res. 98: 1555-1563.

Cohen, E.D., Wang, Z., Lepore, J.J., Lu, M.M., Taketo, M.M., Epstein, D.J., and Morrisey, E.E. 2007. Wnt/ $\beta$-catenin signaling promotes expansion of Isl-1-positive cardiac progenitor cells through regulation of FGF signaling. J. Clin. Invest. 117: 1794-1804.

Dasgupta, C., Martinez, A.M., Zuppan, C.W., Shah, M.M., Bailey, L.L., and Fletcher, W.H. 2001. Identification of connexin43 $(\alpha 1)$ gap junction gene mutations in patients with hypoplastic left heart syndrome by denaturing gradient gel electrophoresis (DGGE). Mutat. Res. 479: 173-186.

Dodou, E., Verzi, M.P., Anderson, J.P., Xu, S.M., and Black, B.L. 2004. Mef $2 c$ is a direct transcriptional target of ISL1 and GATA factors in the anterior heart field during mouse embryonic development. Development 131: 3931-3942.

Ewart, A.K., Morris, C.A., Atkinson, D., Jin, W., Sternes, K., Spallone, P., Stock, A.D., Leppert, M., and Keating, M.T. 1993. Hemizygosity at the elastin locus in a developmental disorder, Williams syndrome. Nat. Genet. 5: 11-16.

Galli, D., Dominguez, J.N., Zaffran, S., Munk, A., Brown, N.A., and Buckingham, M.E. 2008. Atrial myocardium derives from the posterior region of the second heart field, which acquires left-right identity as Pitx2c is expressed. Development 135: 1157-1167.

Garg, V., Kathiriya, I.S., Barnes, R., Schluterman, M.K., King, I.N., Butler, C.A., Rothrock, C.R., Eapen, R.S., HirayamaYamada, K., Joo, K., et al. 2003. GATA4 mutations cause human congenital heart defects and reveal an interaction with TBX5. Nature 424: 443-447.

Garry, D.J. and Olson, E.N. 2006. A common progenitor at the heart of development. Cell 127: 1101-1104.

Gebbia, M., Ferrero, G.B., Pilia, G., Bassi, M.T., Aylsworth, A., Penman-Splitt, M., Bird, L.M., Bamforth, J.S., Burn, J., Schlessinger, D., et al. 1997. X-linked situs abnormalities result from mutations in ZIC3. Nat. Genet. 17: 305-308.

Goldmuntz, E., Geiger, E., and Benson, D.W. 2001. NKX2.5 mutations in patients with tetralogy of fallot. Circulation 104: 2565-2568.

Goldmuntz, E., Bamford, R., Karkera, J.D., dela Cruz, J., Roessler, E., and Muenke, M. 2002. CFC1 mutations in patients with transposition of the great arteries and doubleoutlet right ventricle. Am. J. Hum. Genet. 70: 776-780.

Gollob, M.H., Seger, J.J., Gollob, T.N., Tapscott, T., Gonzales, O., Bachinski, L., and Roberts, R. 2001a. Novel PRKAG2 mutation responsible for the genetic syndrome of ventricular preexcitation and conduction system disease with childhood onset and absence of cardiac hypertrophy. Circulation 104: 3030-3033.

Gollob, M.H., Green, M.S., Tang, A.S., Gollob, T., Karibe, A., Ali Hassan, A.S., Ahmad, F., Lozado, R., Shah, G., Fananapazir, L., et al. 2001b. Identification of a gene responsible for familial Wolff-Parkinson-White syndrome. N. Engl. J. Med. 344: 1823-1831.

Goor, D.A. and Lillehei, C.W. 1975. Congenital malformations of the heart: Embryology, anatomy and operative considerations. Grune and Stratton, New York.

Gutierrez-Roelens, I., Sluysmans, T., Gewillig, M., Devriendt, K., and Vikkula, M. 2002. Progressive AV-block and anomalous venous return among cardiac anomalies associated with two novel missense mutations in the CSX/NKX2-5 gene. Hum. Mutat. 20: 75-76.

Hirayama-Yamada, K., Kamisago, M., Akimoto, K., Aotsuka, H., Nakamura, Y., Tomita, H., Furutani, M., Imamura, S., Takao, A., Nakazawa, M., et al. 2005. Phenotypes with GATA4 or NKX2.5 mutations in familial atrial septal defect. Am. J. Med. Genet. A 135: 47-52.

Hutson, M.R. and Kirby, M.L. 2007. Model systems for the study of heart development and disease. Cardiac neural crest and conotruncal malformations. Semin. Cell Dev. Biol. 18: $101-110$.

Ichida, F., Tsubata, S., Bowles, K.R., Haneda, N., Uese, K., Miyawaki, T., Dreyer, W.J., Messina, J., Li, H., Bowles, N.E., et al. 2001. Novel gene mutations in patients with left ventricular noncompaction or Barth syndrome. Circulation 103: $1256-1263$.

Ikeda, Y., Hiroi, Y., Hosoda, T., Utsunomiya, T., Matsuo, S., Ito, T., Inoue, J., Sumiyoshi, T., Takano, H., Nagai, R., et al. 2002. Novel point mutation in the cardiac transcription factor CSX/NKX2.5 associated with congenital heart disease. Circ. J. 66: $561-563$.

Jerome, L.A. and Papaioannou, V.E. 2001. DiGeorge syndrome phenotype in mice mutant for the T-box gene, Tbxl. Nat. Genet. 27: 286-291.

Kasahara, H. and Benson, D.W. 2004. Biochemical analyses of eight $N K X 2.5$ homeodomain missense mutations causing atrioventricular block and cardiac anomalies. Cardiovasc. Res. 64: 40-51.

Kasahara, H., Lee, B., Schott, J.J., Benson, D.W., Seidman, J.G., Seidman, C.E., and Izumo, S. 2000. Loss of function and inhibitory effects of human CSX/NKX2.5 homeoprotein mutations associated with congenital heart disease. J. Clin. Invest. 106: 299-308.

Kattman, S.J., Adler, E.D., and Keller, G.M. 2007. Specification of multipotential cardiovascular progenitor cells during embryonic stem cell differentiation and embryonic development. Trends Cardiovasc. Med. 17: 240-246.

Kattman, S.J., Huber, T.L., and Keller, G.M. 2006. Multipotent flk- $1^{+}$cardiovascular progenitor cells give rise to the cardiomyocyte, endothelial, and vascular smooth muscle lineages. Dev. Cell 11: 723-732.

Kelly, R.G. and Buckingham, M.E. 2002. The anterior heartforming field: Voyage to the arterial pole of the heart. Trends Genet. 18: 210-216.

Kelly, R.G., Brown, N.A., and Buckingham, M.E. 2001. The arterial pole of the mouse heart forms from $\mathrm{Fgfl0}$-expressing cells in pharyngeal mesoderm. Dev. Cell 1: 435-440.

Kirk, E.P., Sunde, M., Costa, M.W., Rankin, S.A., Wolstein, O., Castro, M.L., Butler, T.L., Hyun, C., Guo, G., Otway, R., et al. 2007. Mutations in cardiac T-box factor gene TBX20 are associated with diverse cardiac pathologies, including defects of septation and valvulogenesis and cardiomyopathy. Am. J. Hum. Genet. 81: 280-291.

Klaus, A., Saga, Y., Taketo, M.M., Tzahor, E., and Birchmeier, W. 2007. Distinct roles of Wnt/B-catenin and Bmp signaling during early cardiogenesis. Proc. Natl. Acad. Sci. 104: 1853118536.

Kwon, C., Arnold, J., Hsiao, E.C., Taketo, M.M., Conklin, B.R., and Srivastava, D. 2007. Canonical Wnt signaling is a positive regulator of mammalian cardiac progenitors. Proc. Natl. Acad. Sci. 104: 10894-10899.

Lalani, S.R., Safiullah, A.M., Molinari, L.M., Fernbach, S.D., Martin, D.M., and Belmont, J.W. 2004. SEMA3E mutation in a patient with CHARGE syndrome. J. Med. Genet. 41: e94.

Laugwitz, K.L., Moretti, A., Caron, L., Nakano, A., and Chien, K.R. 2008. Islet1 cardiovascular progenitors: A single source for heart lineages? Development 135: 193-205.

Laugwitz, K.L., Moretti, A., Lam, J., Gruber, P., Chen, Y., Woodard, S., Lin, L.Z., Cai, C.L., Lu, M.M., Reth, M., et al. 
2005. Postnatal is $11^{+}$cardioblasts enter fully differentiated cardiomyocyte lineages. Nature 433: 647-653.

Lepilina, A., Coon, A.N., Kikuchi, K., Holdway, J.E., Roberts, R.W., Burns, C.G., and Poss, K.D. 2006. A dynamic epicardial injury response supports progenitor cell activity during zebrafish heart regeneration. Cell 127: 607-619.

Li, L., Krantz, I.D., Deng, Y., Genin, A., Banta, A.B., Collins, C.C., Qi, M., Trask, B.J., Kuo, W.L., Cochran, J., et al. 1997a. Alagille syndrome is caused by mutations in human Jagged1, which encodes a ligand for Notch1. Nat. Genet. 16: 243-251.

Li, Q.Y., Newbury-Ecob, R.A., Terrett, J.A., Wilson, D.I., Curtis, A.R., Yi, C.H., Gebuhr, T., Bullen, P.J., Robson, S.C., Strachan, T., et al. 1997b. Holt-Oram syndrome is caused by mutations in TBX5, a member of the Brachyury $(T)$ gene family. Nat. Genet. 15: 21-29.

Li, Y., Bollag, G., Clark, R., Stevens, J., Conroy, L., Fults, D., Ward, K., Friedman, E., Samowitz, W., Robertson, M., et al. 1992. Somatic mutations in the neurofibromatosis 1 gene in human tumors. Cell 69: 275-281.

Lin, A.E., Birch, P.H., Korf, B.R., Tenconi, R., Niimura, M., Poyhonen, M., Armfield Uhas, K., Sigorini, M., Virdis, R., Romano, C., et al. 2000. Cardiovascular malformations and other cardiovascular abnormalities in neurofibromatosis 1 . Am. J. Med. Genet. 95: 108-117.

Lin, L., Cui, L., Zhou, W., Dufort, D., Zhang, X., Cai, C.L., Bu, L., Yang, L., Martin, J., Kemler, R., et al. 2007. $\beta$-Catenin directly regulates Islet 1 expression in cardiovascular progenitors and is required for multiple aspects of cardiogenesis. Proc. Natl. Acad. Sci. 104: 9313-9318.

Lindsay, E.A., Vitelli, F., Su, H., Morishima, M., Huynh, T., Pramparo, T., Jurecic, V., Ogunrinu, G., Sutherland, H.F., Scambler, P.J., et al. 2001. Tbxl haploinsufficieny in the DiGeorge syndrome region causes aortic arch defects in mice. Nature 410: 97-101.

Lindsley, R.C., Gill, J.G., Murphy, T.L., Langer, E.M., Cai, M., Mashayekhi, M., Wang, W., Niwa, N., Nerbonne, J.M., Kyba, M., et al. 2008. Mesp1 coordinately regulates cardiovascular fate restriction and epithelial-mesenchymal transition in differentiating ESCs. Cell Stem Cell 3: 55-68.

Majesky, M.W. 2007. Developmental basis of vascular smooth muscle diversity. Arterioscler. Thromb. Vasc. Biol. 27: 1248 1258.

Martin-Puig, S., Wang, Z., and Chien, K.R. 2008. Lives of a heart cell: Tracing the origins of cardiac progenitors. Cell Stem Cell 2: 320-331.

Marvin, M.J., Di Rocco, G., Gardiner, A., Bush, S.M., and Lassar, A.B. 2001. Inhibition of Wnt activity induces heart formation from posterior mesoderm. Genes Dev. 15: 316-327.

Maslen, C.L., Babcock, D., Robinson, S.W., Bean, L.J., Dooley, K.J., Willour, V.L., and Sherman, S.L. 2006. CRELD1 mutations contribute to the occurrence of cardiac atrioventricular septal defects in Down syndrome. Am. J. Med. Genet. A 140: 2501-2505.

McDaniell, R., Warthen, D.M., Sanchez-Lara, P.A., Pai, A., Krantz, I.D., Piccoli, D.A., and Spinner, N.B. 2006. NOTCH2 mutations cause Alagille syndrome, a heterogeneous disorder of the notch signaling pathway. Am. J. Hum. Genet. 79: 169-173.

McElhinney, D.B., Geiger, E., Blinder, J., Benson, D.W., and Goldmuntz, E. 2003. NKX2.5 mutations in patients with congenital heart disease. J. Am. Coll. Cardiol. 42: 1650-1655.

Meilhac, S.M., Esner, M., Kelly, R.G., Nicolas, J.F., and Buckingham, M.E. 2004. The clonal origin of myocardial cells in different regions of the embryonic mouse heart. Dev. Cell 6: 685-698.

Merscher, S., Funke, B., Epstein, J.A., Heyer, J., Puech, A., Lu, M.M., Xavier, R.J., Demay, M.B., Russell, R.G., Factor, S., et al. 2001. TBXI is responsible for cardiovascular defects in velo-cardio-facial/DiGeorge syndrome. Cell 104: 619-629.

Mikawa, T. and Gourdie, R.G. 1996. Pericardial mesoderm generates a population of coronary smooth muscle cells migrating into the heart along with ingrowth of the epicardial organ. Dev. Biol. 221-232.

Mjaatvedt, C.H., Nakaoka, T., Moreno-Rodriguez, R., Norris,
R.A., Kern, M.J., Eisenberg, C.A., Turner, D., and Markwald, R.R. 2001. The outflow tract of the heart is recruited from a novel heart-forming field. Dev. Biol. 238: 97-109.

Moorman, A.F., Christoffels, V.M., Anderson, R.H., and van den Hoff, M.J. 2007. The heart-forming fields: One or multiple? Philos. Trans. R. Soc. Lond. B Biol. Sci. 362: 1257-1265.

Moretti, A., Caron, L., Nakano, A., Lam, J.T., Bernshausen, A., Chen, Y., Qyang, Y., Bu, L., Sasaki, M., Martin-Puig, S., et al. 2006. Multipotent embryonic $i s l 1^{+}$progenitor cells lead to cardiac, smooth muscle, and endothelial cell diversification. Cell 127: 1151-1165.

Muncke, N., Jung, C., Rudiger, H., Ulmer, H., Roeth, R., Hubert, A., Goldmuntz, E., Driscoll, D., Goodship, J., Schon, K., et al. 2003. Missense mutations and gene interruption in PROSIT240, a novel TRAP240-like gene, in patients with congenital heart defect (transposition of the great arteries). Circulation 108: 2843-2850.

Murry, C.E., Field, L.J., and Menasche, P. 2005. Cell-based cardiac repair: Reflections at the 10 -year point. Circulation 112: 3174-3183.

Naito, A.T., Shiojima, I., Akazawa, H., Hidaka, K., Morisaki, T., Kikuchi, A., and Komuro, I. 2006. Developmental stage-specific biphasic roles of $\mathrm{Wnt} / \beta$-catenin signaling in cardiomyogenesis and hematopoiesis. Proc. Natl. Acad. Sci. 103: 1981219817

Niihori, T., Aoki, Y., Narumi, Y., Neri, G., Cave, H., Verloes, A., Okamoto, N., Hennekam, R.C., Gillessen-Kaesbach, G., Wieczorek, D., et al. 2006. Germline KRAS and BRAF mutations in cardio-facio-cutaneous syndrome. Nat. Genet. 38: 294-296.

Oda, T., Elkahloun, A.G., Pike, B.L., Okajima, K., Krantz, I.D., Genin, A., Piccoli, D.A., Meltzer, P.S., Spinner, N.B., Collins, F.S., et al. 1997. Mutations in the human Jagged1 gene are responsible for Alagille syndrome. Nat. Genet. 16: 235-242.

Oh, H., Bradfute, S.B., Gallardo, T.D., Nakamura, T., Gaussin, V., Mishina, Y., Pocius, J., Michael, L.H., Behringer, R.R., Garry, D.J., et al. 2003. Cardiac progenitor cells from adult myocardium: Homing, differentiation, and fusion after infarction. Proc. Natl. Acad. Sci. 100: 12313-12318.

Olson, E.N. 2006. Gene regulatory networks in the evolution and development of the heart. Science 313: 1922-1927.

Orlic, D., Kajstura, J., Chimenti, S., Jakoniuk, I., Anderson, S.M., Li, B., Pickel, J., McKay, R., Nadal-Ginard, B., Bodine, D.M., et al. 2001. Bone marrow cells regenerate infarcted myocardium. Nature 410: 701-705.

Pashmforoush, M., Lu, J.T., Chen, H., Amand, T.S., Kondo, R., Pradervand, S., Evans, S.M., Clark, B., Feramisco, J.R., Giles, W., et al. 2004. Nkx2-5 pathways and congenital heart disease; loss of ventricular myocyte lineage specification leads to progressive cardiomyopathy and complete heart block. Cell 117: 373-386.

Pehlivan, T., Pober, B.R., Brueckner, M., Garrett, S., Slaugh, R., Van Rheeden, R., Wilson, D.B., Watson, M.S., and Hing, A.V. 1999. GATA4 haploinsufficiency in patients with interstitial deletion of chromosome region 8p23.1 and congenital heart disease. Am. J. Med. Genet. 83: 201-206.

Pizzuti, A., Sarkozy, A., Newton, A.L., Conti, E., Flex, E., Digilio, M.C., Amati, F., Gianni, D., Tandoi, C., Marino, B., et al. 2003. Mutations of ZFPM2/FOG2 gene in sporadic cases of tetralogy of Fallot. Hum. Mutat. 22: 372-377.

Prall, O.W., Menon, M.K., Solloway, M.J., Watanabe, Y., Zaffran, S., Bajolle, F., Biben, C., McBride, J.J., Robertson, B.R., Chaulet, H., et al. 2007. An Nkx2-5/Bmp2/Smad1 negative feedback loop controls heart progenitor specification and proliferation. Cell 128: 947-959.

Qyang, Y., Martin-Puig, S., Chiravuri, M., Chen, S., Xu, H., Bu, L., Jiang, X., Lin, L., Granger, A., Moretti, A., et al. 2007. The renewal and differentiation of $I s l{ }^{+}$cardiovascular progenitors are controlled by a Wnt/ $\beta$-catenin pathway. Cell Stem Cell 1: 165-179.

Robinson, S.W., Morris, C.D., Goldmuntz, E., Reller, M.D., Jones, M.A., Steiner, R.D., and Maslen, C.L. 2003. Missense mutations in CRELDI are associated with cardiac atrioventricular septal defects. Am. J. Hum. Genet. 72: 1047-1052. 
Rodriguez-Viciana, P., Tetsu, O., Tidyman, W.E., Estep, A.L., Conger, B.A., Cruz, M.S., McCormick, F., and Rauen, K.A. 2006. Germline mutations in genes within the MAPK pathway cause cardio-facio-cutaneous syndrome. Science 311: $1287-1290$.

Rubart, M. and Field, L.J. 2008. Stem cell differentiation: Cardiac repair. Cells Tissues Organs 188: 202-211.

Sadr, I.M., Tan, P.E., Kieran, M.W., and Jenkins, K.J. 2000. Mechanism of pulmonary vein stenosis in infants with normally connected veins. Am. J. Cardiol. 86: 577-579.

Satoda, M., Zhao, F., Diaz, G.A., Burn, J., Goodship, J., Davidson, H.R., Pierpont, M.E., and Gelb, B.D. 2000. Mutations in TFAP2B cause Char syndrome, a familial form of patent ductus arteriosus. Nat. Genet. 25: 42-46.

Schneider, V.A. and Mercola, M. 2001. Wnt antagonism initiates cardiogenesis in Xenopus laevis. Genes Dev. 15: 304-315.

Schott, J.J., Benson, D.W., Basson, C.T., Pease, W., Silberbach, G.M., Moak, J.P., Maron, B.J., Seidman, C.E., and Seidman, J.G. 1998. Congenital heart disease caused by mutations in the transcription factor $N K X 2-5$. Science 281: 108-111.

Schubbert, S., Zenker, M., Rowe, S.L., Boll, S., Klein, C., Bollag, G., van der Burgt, I., Musante, L., Kalscheuer, V., Wehner, L.E., et al. 2006. Germline KRAS mutations cause Noonan syndrome. Nat. Genet. 38: 331-336.

Snarr, B.S., Wirrig, E.E., Phelps, A.L., Trusk, T.C., and Wessels, A. 2007a. A spatiotemporal evaluation of the contribution of the dorsal mesenchymal protrusion to cardiac development. Dev. Dyn. 236: 1287-1294.

Snarr, B.S., O’Neal, J.L., Chintalapudi, M.R., Wirrig, E.E., Phelps, A.L., Kubalak, S.W., and Wessels, A. 2007b. Isll expression at the venous pole identifies a novel role for the second heart field in cardiac development. Circ. Res. 101: 971-974.

Snider, P., Olaopa, M., Firulli, A.B., and Conway, S.J. 2007. Cardiovascular development and the colonizing cardiac neural crest lineage. ScientificWorldJournal 7: 1090-1113.

Srivastava, D. 2006. Making or breaking the heart: From lineage determination to morphogenesis. Cell 126: 1037-1048.

Srivastava, D. and Ivey, K.N. 2006. Potential of stem-cell-based therapies for heart disease. Nature 441: 1097-1099.

Stalmans, I., Lambrechts, D., De Smet, F., Jansen, S., Wang, J., Maity, S., Kneer, P., von der Ohe, M., Swillen, A., Maes, C., et al. 2003. VEGF: A modifier of the del22q11 (DiGeorge) syndrome? Nat. Med. 9: 173-182.

Stoller, J.Z. and Epstein, J.A. 2005. Cardiac neural crest. Semin. Cell Dev. Biol. 16: 704-715.

Sun, Y., Liang, X., Najafi, N., Cass, M., Lin, L., Cai, C.L., Chen, J., and Evans, S.M. 2007. Islet 1 is expressed in distinct cardiovascular lineages, including pacemaker and coronary vascular cells. Dev. Biol. 304: 286-296.

Tartaglia, M., Mehler, E.L., Goldberg, R., Zampino, G., Brunner, H.G., Kremer, H., van der Burgt, I., Crosby, A.H., Ion, A., Jeffery, S., et al. 2001. Mutations in PTPN11, encoding the protein tyrosine phosphatase SHP-2, cause Noonan syndrome. Nat. Genet. 29: 465-468.

Topouzis, S. and Majesky, M.W. 1996. Smooth muscle lineage diversity in the chick embryo. Two types of aortic smooth muscle cell differ in growth and receptor-mediated transcriptional responses to transforming growth factor- $\beta$. Dev. Biol. 178: $430-445$.

Tzahor, E. 2007. Wnt/ $\beta$-catenin signaling and cardiogenesis: Timing does matter. Dev. Cell 13: 10-13.

Tzahor, E. and Lassar, A.B. 2001. Wnt signals from the neural tube block ectopic cardiogenesis. Genes Dev. 15: 255-260.

Ueno, S., Weidinger, G., Osugi, T., Kohn, A.D., Golob, J.L., Pabon, L., Reinecke, H., Moon, R.T., and Murry, C.E. 2007. Biphasic role for Wnt/ $\beta$-catenin signaling in cardiac specification in zebrafish and embryonic stem cells. Proc. Natl. Acad. Sci. 104: 9685-9690.

Vissers, L.E., van Ravenswaaij, C.M., Admiraal, R., Hurst, J.A., de Vries, B.B., Janssen, I.M., van der Vliet, W.A., Huys, E.H., de Jong, P.J., Hamel, B.C., et al. 2004. Mutations in a new member of the chromodomain gene family cause CHARGE syndrome. Nat. Genet. 36: 955-957.

Waldo, K.L. and Kirby, M.L. 1993. Cardiac neural crest contribution to the pulmonary artery and sixth aortic arch artery complex in chick embryos aged 6 to 18 days. Anat. Rec. 237: 385-399.

Waldo, K.L., Hutson, M.R., Stadt, H.A., Zdanowicz, M., Zdanowicz, J., and Kirby, M.L. 2005a. Cardiac neural crest is necessary for normal addition of the myocardium to the arterial pole from the secondary heart field. Dev. Biol. 281: 66-77.

Waldo, K.L., Kumiski, D.H., Wallis, K.T., Stadt, H.A., Hutson, M.R., Platt, D.H., and Kirby, M.L. 2001. Conotruncal myocardium arises from a secondary heart field. Development 128: 3179-3188.

Waldo, K.L., Hutson, M.R., Ward, C.C., Zdanowicz, M., Stadt, H.A., Kumiski, D., Abu-Issa, R., and Kirby, M.L. 2005b. Secondary heart field contributes myocardium and smooth muscle to the arterial pole of the developing heart. Dev. Biol. 281: 78-90.

Watanabe, Y., Benson, D.W., Yano, S., Akagi, T., Yoshino, M., and Murray, J.C. 2002. Two novel frameshift mutations in $N K X 2.5$ result in novel features including visceral inversus and sinus venosus type ASD. J. Med. Genet. 39: 807-811.

Wu, S.M. 2008. Mesp1 at the heart of mesoderm lineage specification. Cell Stem Cell 3: 1-2.

Wu, S.M., Fujiwara, Y., Cibulsky, S.M., Clapham, D.E., Lien, C.L., Schultheiss, T.M., and Orkin, S.H. 2006. Developmental origin of a bipotential myocardial and smooth muscle cell precursor in the mammalian heart. Cell 127: 1137-1150.

Yagi, H., Furutani, Y., Hamada, H., Sasaki, T., Asakawa, S., Minoshima, S., Ichida, F., Joo, K., Kimura, M., Imamura, S., et al. 2003. Role of TBX1 in human del22q11.2 syndrome. Lancet 362: 1366-1373.

Yang, L., Soonpaa, M.H., Adler, E.D., Roepke, T.K., Kattman, S.J., Kennedy, M., Henckaerts, E., Bonham, K., Abbott, G.W., Linden, R.M., et al. 2008. Human cardiovascular progenitor cells develop from a $\mathrm{KDR}^{+}$embryonic-stem-cellderived population. Nature 453: 524-528.

Yelbuz, T.M., Waldo, K.L., Kumiski, D.H., Stadt, H.A., Wolfe, R.R., Leatherbury, L., and Kirby, M.L. 2002. Shortened outflow tract leads to altered cardiac looping after neural crest ablation. Circulation 106: 504-510.

Zatyka, M., Priestley, M., Ladusans, E.J., Fryer, A.E., Mason, J., Latif, F., and Maher, E.R. 2005. Analysis of CRELD1 as a candidate 3p25 atrioventicular septal defect locus (AVSD2). Clin. Genet. 67: 526-528.

Zhao, F., Weismann, C.G., Satoda, M., Pierpont, M.E., Sweeney, E., Thompson, E.M., and Gelb, B.D. 2001. Novel TFAP2B mutations that cause Char syndrome provide a genotype-phenotype correlation. Am. J. Hum. Genet. 69: 695-703.

Zhou, B., Ma, Q., Rajagopal, S., Wu, S.M., Domian, I., RiveraFeliciano, J., Jiang, D., von Gise, A., Ikeda, S., Chien, K.R., et al. 2008. Epicardial progenitors contribute to the cardiomyocyte lineage in the developing heart. Nature 454: 109-113. 


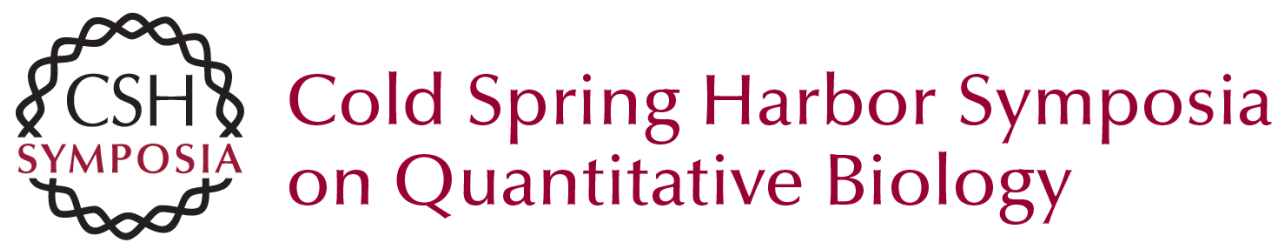

\section{Multipotent Islet-1 Cardiovascular Progenitors in Development and Disease}

A. Nakano, H. Nakano and K.R. Chien

Cold Spring Harb Symp Quant Biol 2008 73: 297-306 originally published online February 9, 2009 Access the most recent version at doi:10.1101/sqb.2008.73.055

References This article cites 115 articles, 26 of which can be accessed free at: http://symposium.cshlp.org/content/73/297.full.html\#ref-list-1

\section{License}

Email Alerting Receive free email alerts when new articles cite this article - sign up in the box at the Service top right corner of the article or click here. 